\title{
MUSEUMS, SOCIO-ECOLOGICAL THINKING, AND ACTIVIST PEDAGOGIES OF IMAGINATION
}

\begin{abstract}
This article explores the complex, "contact zone" nature of museums within the context of the current environmental crisis threatening our planet. Historically and even today, museums have engaged in a practice of "monocultural" thinking which is mired in a pretext to neutrality that has advanced the patriarchal capitalist neoliberal status quo and maintained a vision of a human/non-human binary of power, dominance, and control. However, there is also growing evidence that museums are shifting their approaches. Focusing on examples from Canada, we discuss how museums are using exhibitions and pedagogical and community outreach strategies to render visible deeply problematic and global "technofossil" practices, encourage activism through aesthetic engagement, encourage dialogue between community and industry as well as engage in imaginative decolonising initiatives that remap our understandings of who we are and where we need to go. We argue that in taking up environmental issues in politically intentional ways, museums create "oppositional views" that act as pedagogical sites of resistance.
\end{abstract}

Keywords: museums, art galleries, ecofeminism, sustainability, Indigenous art

\section{MUZEII, SOCIOEKOLOŠKO RAZMIŠLJANJE IN AKTIVISTIČNE PEDAGOGIKE DOMIŠLIIJE - POVZETEK}

Preučujemo kompleksno naravo muzejev kot »območij stika «v kontekstu okoljske krize, ki ogroža naš planet. V preteklosti je v muzejih obstajala in tudi zdaj obstaja praksa »monokulturnega « razmišljanja, ki se izdaja za nevtralno, pravzaprav pa podpira patriarhalno kapitalistični in neoliberalni status quo ter ohranja binarij med človeškim in nečloveškim na področju delitve moči, prevlade in nadzora. Vendar pa vse več muzejev spreminja svoj pristop. Osredotočamo se na muzeje v Kanadi, ki z razstavami, pedagoškimi strategijami in vključevanjem lokalnih skupnosti omogočajo prepoznavanje globoko problematičnih globalnih praks »tehnofosilov«. Aktivizem spodbujajo tako, da obiskovalca estetsko pritegnejo, krepijo dialog med skupnostjo in industrijo ter se ukvarjajo z iznajdljivimi pristopi do dekolonizacije, ki na novo rišejo zemljevid našega razumevanja tega, kdo smo in kam gremo. Muzeji, ki intencionalno

Lauren Spring, PhD candidate, University of Toronto, lauren.spring@mail.utoronto.ca

Darlene Clover, PhD, Prof., University of Victoria, clover@uvic.ca 
in politično obravnavajo vprašanja okoljevarstvene problematike, ustvarjajo »opozicijske poglede« in s tem pedagoška prizorišča upora.

Ključne besede: muzeji, galerije, ekofeminizem, trajnost, umetnost domorodnih ljudstev

\section{INTRODUCTION}

The burgeoning literature on the environmental crisis acknowledges what Janes (2009) calls the "constellation of issues that threaten the very existence of human life and planet" and offers a variety of possible resolutions to this dire condition through sustainability education (p. 26). Surprisingly, or perhaps not as we will discuss in this article, Janes has found that museums "are rarely, if ever, discussed" in this literature, leading him to conclude that their irrelevance to environmental justice and change "is a matter of record" (p. 26). Similarly, until very recently, museums have been excluded from discourses of lifelong learning and particularly, environmental adult education.

However, these institutions are major, albeit complex, pedagogical players on the world stage. Conservation and preservation of both the natural and human culture worlds are central functions of our art and culture institutions, yet visitors tend to frequent museums to learn, be it about history, aesthetics, science, nature or even themselves (e.g. Gordon-Walker, 2018; Marstine, 2006). In other words, as UNESCO (1997) once argued, museums are "first of all, learning places" (p. 4) and this has expanded into a greater mandate over the years with the establishment of actual education or what are more often called learning departments. Through practices of informal learning, non-formal and formal education and strategies of community engagement, museums use their exhibitions - displays, objects, artefacts, dioramas, images, artworks, explanatory texts as well as other narrative and visual devices - to construct, shape and mobilise knowledge (e.g. Clover \& Spring, 2020; Hall et al., 2013; Whitehead, 2009). Equally importantly, "exhibitions are designed to stimulate the imagination and creativity of their viewers" (UNESCO, 1997, p. 6) and for Solnit (2014) "the destruction of the earth is due in part [...] to a failure of the imagination" (p. 14).

Given the variety of educational and learning activities and experiences, their community connections and the intentional imaginative visualising and narrative capacities of their exhibitions, one might assume museums would be seen to have a central role in addressing the pressing socio-ecological issues of the Anthropocene, our current geological epoch where humans are irrevocably impacting the environment. However, scholars remind us that the knowledge-making practices of museums can be deeply problematic. Ample evidence shows they have been complicit in upholding and even promoting the ideological and epistemological assumptions that have brought us to our current state of crisis (e.g. Alberti, 2008; Clover et al., 2018; Janes, 2009; Machin, 2008). Yet arguments to the contrary insist that amidst the litany of growing social and environmental ills, our public art and cultural institutions are in fact "sleeping giants" whose adaptive power, which has enabled them to grow and evolve over the decades and thus stay central to society, 
is enabling them to transform into agents of change with "the potential to shape a more sustainable, equitable and fair world" through envisioning and presenting the potential for micro, meso and macro level changes (Janes \& Sandell, 2019, p. xxvii).

In her book Monoculture of the Mind, eco-feminist Vandana Shiva (1993) speaks to the unsustainable practice of "single crop" or "monoculture farming" that has been imposed upon many Indigenous people the world over by Western scientists. It is now widely recognised that this approach to farming (in which the same crop is planted in the same spot every year) depletes the richness of the soil and necessitates the use of strong chemical fertilizers, which bring with them a whole host of other long-term environmental problems. Shiva cleverly uses this concept of a "monoculture" in an agricultural sense, however, as a metaphor for exploring bigger questions about what counts as "knowledge" when it comes to environmental education. For example, she relates the way traditional sustainable farming practices in the global south are often "eclipsed and finally destroyed, both through neglect and aggression" when western knowledge is seen as universal (p. 5). This "monocultural" approach to both farming and knowledge production/sharing is unsustainable - and deprives us from accessing the richness of alternative perspectives (p. 5). Gregorčič (2018) has addressed similar questions, arguing that the practice of silencing certain individuals from the global south along with their "specific expertise, knowledge, and sometimes even epistemology" is both pedagogically detrimental and indicative of the ways that certain perspectives are "ignored by Western science and forgotten by Eurocentric critical tradition" (pp. 70-71).

In this article we critique the ways in which monocultural/unsustainable thinking has historically been found in museum spaces and reflect on the types of knowing that have been excluded as a result. We also explore how museums as public institutions are shifting their approach — especially when addressing head on our global environmental crisis and issues of sustainability. As museum scholars and practitioners, what we are taking up through these dual lenses of positive and negative is that idea that museums are "contact zones", fraught with practices that reinforce the status quo yet also at times sites of possibility and imagination, the tonics we need today (Clover \& Sanford, 2016). In this context, we begin our article with a discussion of some of the problematic ideological and epistemological conventions which illustrate museums' historical and contemporary complicity in the perpetuation of socio-ecological injustice. Following this we share select examples from several museums within Canada where we are both located, to illustrate how museums are educating formally, non-formally and informally, imaginatively and critically for change. Although many public museums continue on traditional journeys of epistemological complicity and resistance to change, there are courageous pedagogical energies, creative and innovative initiatives, and counter-hegemonic strategies being employed. We argue that these pedagogical acts of what we adult educators often call "the possible" are playing a part in creating a more engaged and knowledgeable citizenry and as such, expand our considerations of what lifelong learning looks like and where it is taking place in the Anthropocene. 


\section{MUSEUMS, IDEOLOGICAL AND EPISTEMOLOGICAL COMPLICITIES}

Ecological educator Evans (2012) argues that we have "unleashed a juggernaut of self-perpetuating and self-reinforcing systems of power and exploitation" which has placed human societies and all other forms of life across the planet in jeopardy (p. 3). These systems are in fact inter-connected ideological and epistemological assumptions grounded in, maintained and perpetuated through our educational, social and political practices but most importantly for us in this article, by our arts and cultural institutions. We turn now to some of the reasons why museums would be seen as "irrelevant" in a world that in fact desperately needs all its public institutions to play pedagogical roles in creating socio-environmental change.

To begin with perhaps the most obvious, museums carry legacies of elitism. On one hand, elitism has enabled a pervasive didactic pedagogy, a practice of "telling" based in a profound belief in their unequivocal superiority of authority of knowledge. Much like the "monoculture" farming practices Shiva (1993) addresses in which "dominant scientific knowledge" renders other forms of knowing "invisible" by declaring them "non-existent or illegitimate" (p. 4), this elitism in museum spaces is nurtured behind a carefully constructed façade of neutrality, impartiality and objectivity, and a pretext to "detachment from real-world politics" (Phillips, 2011, p. 8). This façade has been so effective that museums are amongst the most trusted of all our knowledge constructing and legitimating institutions (e.g. Alberti, 2008; Gordon-Walker, 2018).

For Janes (2009), elitism and impartiality work together to eschew "on both moral and practical grounds, a broader commitment to the world in which they operate" (p. 13). Museums are in fact far from neutral; indeed, they are awash in the problematic assumptions and what Code (2003) calls "epistemologies of mastery" that they intentionally, actively and often quite imaginatively transmit to the public. One pervasive ideological epistemology of mastery practised traditionally and still very much alive in the present, is patriarchy (Clover et al., 2018). Although many poignant examples exist, an excellent one comes from a study by Machin (2008) who used a feminist lens to explore the natural history galleries of the Manchester Museum, UK. She found androcentric biases across all the displays; "male specimens dominated female specimens with respect to number, the postures and positions in which they were displayed, and in the quantity and style of language used in interpretative text" (p. 54). Through both image and language museums channel patriarchal epistemologies of domination, oppression and exploitation which are absorbed by visitors both consciously and unconsciously.

Building on the above, the advancement of patriarchal capitalist neoliberal ideology is also embedded within the museum in complex ways. Historical narratives told through objects, texts and representations such as dioramas in Canadian museums, for example, romanticise masculinised accounts of natural resource extraction including logging, fishing, mining, agricultural expansion and manufacturing. These powerful hegemonic patriarchal narratives of national building are almost totally disconnected from dioramas of pristine natural settings. Pedagogically, this acts as what Alberti (2008) calls 
"illusionism" through the "meticulous verisimilitude of the diorama" both to distance human activities from the rest of nature and to make or allow us to see particular legitimised realities (p. 76). In addition, museums such as the Canadian Museum of History, Tate Modern and the British Museum have partnerships with the fossil fuel industry. The museums receive funding and "direction", and big oil industries use this relationship to create an image of social and ecological license and responsibility (Coalition of Museums for Climate Justice, 2017; Serafini \& Garrad, 2019).

Returning to the practice of distancing, by creating "natural history" museums or simply placing natural history on one floor of an institution and human culture on another, museums cultivate visual "oppositional nature/culture configurations" and create divisive binaries between humanity and the rest of nature (Alberti, 2008, p. 81). Moreover, this separation or segregation of artefacts (things made by humans) from "specimens" from the natural world is based in what feminist's call hierarchical value judgments (e.g. Bergsdottir, 2016; Clover \& Sanford, 2016; Machin, 2008). In other words, segregating is not neutral or objective but an act of privileging the story of humanity - and particularly some humanity - over the natural world which plays the role of mise-en-scene, the backdrop to human activity. Yet the current climate crisis makes one thing abundantly clear: "natural history and human history are more intertwined than ever. Humans have become a force of nature. One cannot separate humans or society from nature, and nature does not simply provide a background for human action" (Chakrabarty, 2019, p. 15).

Just as human-earth separations are no accident, neither, Alberti (2008) argues, was it an accident that global colonial expansions "were matched by the unprecedented foundation and expansion in museums" (p. 76). One means by which museums practised colonialism was through displays of "trophy heads [...] symptomatic of the central role played by hunting" in colonial times (p. 76). This particular hunting was for sport, a masculinity of colonial prowess that showed blatant disregard for other life forms. But perhaps even more damaging has been museum complicity in the epistemicide of Indigenous knowledges and cultures. When included at all in the displays, Indigenous people's lives are often visualised as "frozen in time, relics of the past [devoid of their] centuries of social, domestic and economic changes" (Trofanenko, 2006, p. 53). Indigenous world creation stories too are labelled "myths" and juxtaposed (read "corrected") with panels that explain the "real" science behind the world. There is a blatant exclusion as well of any discoveries that cast light upon Indigenous practices of chemistry and other "real" scientific knowledge capabilities about the environment (Emeagwali \& Shizha, 2016). Moving along the path of epistemicide is the cultural exclusion of Indigenous artworks and practices. Relegated for decades to categories of mere craft (versus "fine" art) or simply religious or ritual artefact, these rich aesthetic practices have been diminished. And never does one see the parallel drawn with many European religious paintings by so-called "masters" which were in fact commissioned for similar veneration purposes.

These are but a few examples of the problematic inseparability between ideology and the pedagogy of knowledge making in museums. We have simply touched the surface of how 
these institutions use an array of visuals, images, dioramas, objects, artefacts as well as their storytelling capacities to teach us what is important to see, to know, to understand and thus to believe and to value about the world and ourselves. There exist thousands of museums worldwide, visited by millions of people daily who, as we noted above, both consciously and unconsciously absorb these injustices. This is not to say people do and cannot question what they see or are being told, but as we noted, the museum's authority of knowledge gives them extraordinary legitimacy.

Given what we have just outlined above it is no surprise at all that museums would be seen at best as irrelevant to a world needing to learn its way out of a catastrophic socio-ecological mess. However, this is not the entire story because there are collisions between normative practices and more radical forms of pedagogical intervention taking place. Responding to intense pressures both within and outside these institutions, many are throwing off the shackles of neutrality to become sites of social and ecological transformation (e.g. Janes \& Sandell, 2019; Phillips, 2011). Museums are opening up pedagogical spaces of counter-narrative, designing formal and non-formal education activities and informal learning spaces to enable people to reflect, to challenge, to speak out, to uncover and to reimagine our relationship with the planet and each other.

\section{MUSEUM RESOURCES AND ENVIRONMENTAL SUSTAINABILITY}

In order to understand the innovative roles museums are attempting to play it is important first to situate them in the calls by educators who are working to prepare themselves and others to engage in what Evans (2012) calls "sustainability-oriented actions" to address the crisis caused by our very own human institutions and their systems of power (p. 3). These calls are inter-connected and three-fold. The first is simply a call for more public pedagogical spaces where people can come together to learn. Biesta (2012, p. 684) noted a serious decline in public places and the public sphere which he argues is damaging to both democracy and creativity. The second call is for practices that engage and stimulate critical consciousness by promoting dialogue across difference, encouraging questioning and other forms of interrogation that can enable us to see and act beyond our current common sense patriarchal capitalist and colonial world (e.g. Clover et al., 2012). For Klein (2014) this means providing opportunities to make sense of

seemingly disparate struggles $[\ldots]$ that the logic that would cut pensions, food stamps, and health care before increasing taxes on the rich is the same logic that would blast the bedrock of the earth to get the last vapours of gas and the last drops of oil before making the shift to renewable energy. (p. 59)

The third call focuses on the imagination (e.g. Clover et al., 2012). Speaking directly about the environmental crisis as a practice of "slow violence", Nixon (2011) argues that we must deploy more "imaginative agility" if we are to fully apprehend threats such as climate change that are often imperceptible to cognition (p. 5). He focusses on storytellers 
who provide narratives infused with an emotional force that interrupts the epistemologies of mastery that hold in place a problematic social imaginary. For Arundhati Roy this means "telling our own stories, stories different to those we are being brainwashed to believe" (quoted in Clover et al., 2012, p. 54; Clover et al., 2018). Environmental adult educators speak to this as the resistant political and ecological imaginary, a process through which environmental problems can be politically and critically thought through and creatively re-imagined (e.g. Clover et al., 2012). In his ground-breaking writings on environmental education, Orr (1996) differentiates between "fast knowledge" and "slow knowledge", arguing that the former "undermines long-term sustainability" (p. 700). He says:

The $20^{\text {th }}$ century is the age of fast knowledge driven by rapid technological change and the rise of the global economy. This has undermined communities, cultures, and religions that once slowed the rate of change and filtered appropriate knowledge from the cacophony of new information. (p. 699)

In spite of their flaws, museums are in fact well placed to respond to these calls and, in many ways, are ideal "slow knowledge" institutions. Many museums have a variety of public physical resources such as auditoriums, classrooms, and workshop spaces for artmaking that can be used to bring people together in dialogue (Lyons \& Bosworth, 2019). Secondly, the primary instruments museums use to educate the public are their exhibitions. These are "free choice informal adult learning" (Johnson, 2020, p. 9) instruments that include an array of visuals and narrative representations that function as what Steeds (2014) calls "plays of force [...] to influence the public" (p. 29). Thirdly, many museums have connections to artists with histories of responding to the upheavals and changes of their times, interpreting and representing these in visual, poetic, narrative and performative ways that encourage thought beyond the restrictions of mere logic and language (Clover et al., 2018). Fourthly, museums have connections to community groups, non-governmental organisations and practitioners upon whom they can call. Finally, as we stated earlier, museums enjoy a very high degree of public trust. While this can be problematic, it is a position that can be used to their advantage.

\section{DIVERSE PEDAGOGICAL STRATEGIES OF ACTIVISM}

What are some of the pedagogical means being employed by museums that intentionally challenge the crisis representation, story and imagination that have brought us this troubled world? How might museums help foster slow knowledge that "engages all of the senses and the full range of our mental powers?" (Orr, 1996, p. 701)

\section{Visualising and Educating Change}

Feminist cultural theorists Carson and Pajaczkowska (2001) remind us that visuals and images are powerful because they are "the seen" and sight more than any other sense is "considered evidence, truth and factual" (p. 1). Moreover, sight establishes "a particular 
relation to the reality in which a visual is considered" (p. 1), which is problematic but equally, in the case of this example we are about to unfold, valuable when it is a trusted space such as a museum.

A recent example that illustrates the power of "seeing" while also responding to Nixon's (2011) call for "imaginative agility" and the "full range of our mental powers" mentioned above, is The Anthropocene Project. This endeavour - part film, part museum exhibition - was the culmination of a collaboration by photographer Edward Burtynsky and filmmakers Jennifer Baichwal and Nicholas de Pencier. The trio travelled to every continent (except Antarctica) to film and photograph "technofossils" of all sorts (tailings ponds, mines, landfills - the indelible "signature", essentially, of the "human epoch") (Art Gallery of Ontario, 2017, 2018). The film associated with the project premiered at the Toronto International Film Festival in September 2018 and the immersive photography exhibitions opened at the Art Gallery of Ontario in Toronto and the National Gallery in Ottawa a few weeks later. The large-scale sweeping photographs are aesthetically enticing as the compositions themselves appear to exist somewhere between figuration and abstraction. Burtynsky argued that there was a certain critical pedagogy at the core of these exhibitions. The visually stunning images are designed to draw viewers in and hold their attention long enough for a certain tension to reveal itself-until one is ultimately unable to avert their eyes from the destruction our species has caused and our individual and collective complicity at play. The sense of awe and wonder these photographs instil helps ensure that the exhibition as a whole is "revelatory and not accusatory" in nature (Art Gallery of Ontario, 2017). The artists also sought to create a "dialectics of scale" by allowing viewers to "zoom in" to certain aspects of these large photos where, via the use of an iPad app, viewers could travel from macro to micro as aspects of images came to life in video form and interviews with people who reside near and sometimes depend on these vast sites to make a living helped complicate the messaging (Art Gallery of Ontario, 2018). The ironic controversy, of course, is that the very iPads viewers were using to activate this important learning, were running on lithium batteries - key elements of which were extracted from the mines depicted in some of the photographs on display (Clover \& Spring, 2020).

Another key feature of the exhibition was Augmented Reality (AR) installations, where, through the use of iPads, visitors could "activate" what appeared to be a large cube (that actually contained thousands of specific images "photogrammetrically mapped onto a virtual volume") in order to be virtually transported to another time and place as images representing endangered species (the last northern male white rhino, an enormous Douglas fir tree, and a breath-taking funeral pyre of 10,000 confiscated elephant tusks that were set alight in Nairobi so as to discourage ivory poaching) were brought to life before their eyes. This AR experience represents something new in museum education and raises compelling pedagogical questions. In his influential work on "ecoliteracy", Monty Hempel (2014) furthers arguments made by David Orr (2004) on the same subject to conclude, essentially, that exclusively science-based approaches to understanding the environment can only take us so far and that, as a species, we are in great need of visceral 
learning, or a "nature-based attachment to place" (Hempel, 2014, p. 45) if we are to more deeply understand "the complex natural systems that enable and support life on earth" (p. 34). Hempel cites a powerful example of his own university students developing an emotional connection to the natural world while witnessing coral-bleaching up close while on a research trip to the Republic of Palau. Though it may be easy to embrace the idea that much of ecoliteracy takes place outside of the traditional classroom setting, if we are wary of our own ecological footprints (and can't justify, say, flying halfway around the world to see and connect with environmental wonders), might AR experiences such as the one offered in the Anthropocene exhibition be the next best thing? And what about making use of this technology to facilitate visceral learning as it pertains to species that are already extinct and we are hence unable to connect with in person? Or in order to transport us to once-in-a-lifetime environmental events such as the devastating and poetic setting ablaze of thousands of elephant tusks? We would argue, however, that even less technologically inclined paintings and sculptures whose creators have a particularly deep cultural knowledge of the environments they represent provide viewers with a nature-based knowledge.

Exhibitions such as this illustrate the role museums are playing by creating visceral learning and ecoliteracy pedagogies in the age of the Anthropocene.

\section{Bridging Community and Industry}

Perhaps the most divisive ecological issue in Canada today is the "oil sands" energy project. Rather than staying neutral and apart, however, a small museum in Kitimat, British Columbia, decided to encourage the community to use the museum as a conduit to ask provocative and difficult questions and channel these directly to industry.

The Kitimat museum is located at the terminus of a most controversial pipeline project to carry thousands of barrels of "diluted bitumen per day from the oil sands of Alberta across Rocky and Coast mountain ranges, salmon spawning rivers and Indigenous territories" and onto "supertankers" (large tanker ships) to be shipped aboard for refining through extremely narrow and hazardous (shoals, eddies, storms) passages (Bell \& Clover, 2017, p. 23). The Kitimat Museum staff called upon local citizens and artists to help them to create an exhibition that explored the issue of energy production creatively and from a variety of other angles (Bell \& Clover, 2017). The museum staff also gathered questions from the community about energy production and social and ecological issues, which they grouped into themes such as economy, activism, risk, and consultation and presented to officials in both government and the petroleum/pipeline industry for their responses. The pipeline initiative has been pulled from the table.

\section{Spectacular Defiance}

Building on the above and dealing with the same issue, the Haida Gwaii museum in British Columbia curated in summer 2013 a powerful activist exhibition entitled Thanks but no Tanks. To design the exhibition, they called for representations by native and non-native artists to produce a radical display "of opposition to the proposed oil pipeline and increased 
numbers of oil tankers on the Pacific coast of British Columbia" (Leichner, 2013). This defiant practice of representational cultural activism that entered fully into the crisis was filled with hard-hitting and satirical works, a multi-media mixture of photography, cartoons, paintings, and poetry that juxtaposed government conceived economic opportunities with the real socio-ecological threats (everything from spills to drugs) the pipeline presents. The exhibition also included a collision of oppositional statements by Native elders on one side and pipeline proponents on the other. The museum used the exhibition as a platform to animate community discussions, which could be heated, and to develop popular theatre activities that continue to generate considerations about our use of oil (Bell \& Clover, 2017).

\section{Undoing Colonial Legacies}

The ground-breaking Truth and Reconciliation Report (2012) in Canada emphasised that "museums [...] as sites of public memory and national history, have a key role to play in national reconciliation" (p. 246). Indigenous peoples' ways of being have profound implications for human-earth relations. As Forest-Hammond (2020) writes, Indigenous peoples have since time immemorial been stewards of the lands, plants, and waters, treating them with reciprocity, "mutual care and respect" (p. 94). In countries like Canada, with particularly brutal colonial histories, the involvement of Indigenous people in museum programming and the representation of Indigenous worldviews in gallery spaces helps provide a powerful counterpoint to Shiva's (1993) "monoculture of the mind".

The frequently conflicting worldviews held by coloniser and Indigenous communities in Canada is reflected in historic and contemporary art in powerful and revealing ways. At the Art Gallery of Ontario (AGO) in recent years, efforts have been underway to decolonise its Canadian art collection. While there is no specific definition of decolonisation, it includes reconfiguring "the power relationships between colonisers and colonised and open[ing] new spaces in which it became possible to critically engage with and analyse the mechanisms that had created, justified and perpetuated the system of Western colonialism" (Porr \& Mathews, 2019, p. 5).

In addition to increasing the number of works by Indigenous artists on display and giving Anishinaabemowin priority of place (before English and French) on interpretive text wall panels, a special role, Curator of Indigenous Art, was created in 2017. Wanda Nanibush, the curator who took up the position has said the following:

decolonisation means letting Indigenous people lead. Decolonisation involves unlearning and changing what colonialism is based on in terms of private property, manifest destiny, "discovery", Enlightenment, Eurocentrism, Cartesian dualism, hetero-patriarchy, capitalism, positivism, sexism, racism, individualism, extraction, classism, violence and control. Decolonisation should challenge all that is thought to be proper and normal in current settler colonial states. Decolonisation involves a centring of Indigenous ways of being, knowing and loving. (Mignolo \& Nanibush, 2018, p. 25) 
One especially powerful artwork from the AGO that exemplified these objectives was created at the same time as the Truth and Reconciliation Commission was garnering widespread attention. Bonnie Devine's Battle for the Woodlands provided an opportunity for a new "public pedagogical space" both while it was being created and for the questions it helped spark after its completion. In 2014-2015, Devine, who is an artist, educator, and a member of the Serpent River First Nation, was invited to create an installation in the Canadian collection. In response to a problematic colonial map from the 1830s that had long been displayed on the gallery wall, Devine worked in place to tell a very different story about the history of this land and how it might alternately be represented. Though a full unpacking of this complex piece is beyond the scope of this paper, Devine's depictions of water were particularly striking. Devine not only literally drew on top of the existing map, but also extended her pictorial representations onto the surrounding walls (Art Gallery of Ontario, 2015). The most noticeable feature of the installation is the way she transformed the Great Lakes into large animals - each with its own power and temperament - and painted the rivers leading into them in a striking red. About this, Devine argues:

This map really is a product of reading, thinking and dreaming and imagining what it really means to live on these Great Lakes. What it means to have blood running inside your veins of these people who fought to protect these lakes and what the lakes mean themselves. That's why I made them into animals because they aren't just bodies of water. They are beings who are cohabiting with us in this space right now. They are living. We are in a relationship with them. We have been for many hundreds of years [...] It's very deep and old. It hasn't got a lot of words. I don't have the words for it; all I have are these images and these figures. It's my way of talking about this very, very ancient consanguinity, which means having the same blood, it means water that is running lakes and rivers runs in us. That's what I'm trying to say (Commanda, 2016, para. 11).

This way of understanding and representing these bodies of water is very much in keeping with how other Indigenous communities who live near the Great Lakes describe them as well. For example, following the Walkerton water tragedy in Ontario in 2000, the Chiefs of Ontario on traditional knowledge and water held a series of community workshops out of which were developed the key messages to submit to the Walkerton inquiry. One of these messages was: "Water is alive. It is a being with its own spirit [...][;] water bodies are thought to have various responsibilities that require different demonstrations of respect" (McGregor 2012, p. 10).

Devine's Battle for the Woodlands was an especially rich work to include on tours with visitors to the AGO. For months, while Devine was working on location in the actual gallery space, there was a sign that indicated that she would be pleased to discuss the process and the work with those walking by and this provided a unique and meaningful opportunity for dialogue and community engagement. Additionally, because the work 
was large-scale and intentionally provocative, visitors were provoked into asking important questions about treaties and the conflicting histories to what they had been taught that were depicted on the walls. Conversations queried the challenges that had been brought about by how, for example, European settlers (represented by sailboats coming in from the east) viewed bodies of water differently (as commodity, means of travel, passages to be militarised, etc.). These discussions with groups also helped open doors to timely conversations about the lack of safe drinking water on reserves throughout the country and other troubling facts about poor living conditions, intergenerational trauma, and the complexities of reconciliation. This work and specifically Devine's representation of the Great Lakes also help highlight how colonialism, capitalism, and numerous other driving forces behind the Anthropocene and related environmental, political, and civil injustice are intricately linked to patriarchal epistemologies. Deborah McGregor (2012), an Indigenous scholar and water activist has said:

In the Anishinabe tradition, women have a special relationship with water, since, like Mother Earth, they have life-giving powers. Women have a special place in the order of existence. They provide us, as unborn children, with our very first environment - water [...] with this special place in the order of things come responsibilities [...] In some ceremonies, women speak for water. (p. 3)

Vandana Shiva's (Jahanbegloo \& Shiva, 2013) ecofeminist theory similarly argues that there is a "relationship between women's liberation and a struggle for the liberation of life on earth" (p. 49). Thus, museums' efforts to confront the Anthropocene and its related ideologies and injustices also make visible their own legacies of erasure and upholding of the Eurocentric status quo.

\section{FINAL THOUGHTS ON MUSEUMS AS SITES OF LIFELONG LEARNING}

Museums have and will continue to be problematic spaces based in ideological assumptions that have contributed to the knowledge and imagination deficits central to our current state of socio-ecological devastation. Elitism, impartiality, patriarchy, colonialism, capitalism, and human-nature dualisms. This "monocultural" thinking, as we argued, is ingrained in the structures and this guarantees that these institutions will remain irrelevant to the struggles of learning, storying, imagining our way out of this current state of peril. However, what we also show in this article is this is not the entire story of these complex "contact zones" and it is therefore critical to populate the museum terrain with examples that acknowledge them as sites of struggle that are working to make a difference. They are in fact making important visual and narrative contributions to lifelong learning. In other words, while many museums, in ways similar to the "fast knowledge" Orr (1996) critiques, arise from "hierarchy and competition", they also have their sights set on developing a more sustainable "slow knowledge" approach wherein knowledge is "freely shared within community" (p. 701). 
In taking up environmental issues, museums are bringing to lifelong learning an "opposition look" at effects and solutions. Oppositional looks in particular act as what Bloom (1999) called "a site of resistance" to the normative ways in which we have been made to see and thus to understand our current ecological crisis. Encouraging oppositional "looks" moves us away from their conventional forms of visual detachment towards placing visitors into positions of "viewing agency" through a more embodied or immersive subjective viewing process. Oppositional looking is about perspective and perspective is being made into an act of transforming the material we see into very new meanings. Secondly, and building on the notion of agency, museums are actively encouraging a sense of political agency, something critical to lifelong learning's hope for an engaged citizenry and micro, meso and macro level change. Museums, as we have illustrated, are doing this by engaging visitors or Indigenous artists in the creation of exhibitions. This not only renders their voices and works visible in the public sphere but in some cases, museums are using their own agency to take the political voices to government and boardroom as well. Museums also contribute to lifelong learning by providing space for "dangerous conversations", be that in the form of re-languaging exhibitions in ways that call attention to the role of the oil industry or by providing spaces where people can come together to question colonialism and its impact on people, the environment, and our entire knowledge system. To borrow from Jahanbegloo and Shiva (2013), they allow us to both read and see "connections where capitalist patriarchy and its warrior science are engaged in disconnecting and dissecting" the living whole that makes up our world (p. 3).

By throwing off the shackles of neutrality and riding on the laurels of public trust, many museums are broadening what can be seen, taught, thought and imagined in and of the Anthropocene with courage, humour and tenacity. Another vital image represented in Bonnie Devine's Battle for the Woodlands was a small painting of the dish with one spoon. This concept was often built into treaties between Indigenous people of the Great Lakes region in North America and those colonising the land. The dish with one spoon concept and image represents a sharing of resources in a sustainable fashion. The dish symbolises the land (which doesn't belong to anyone, but is to be shared peacefully) and the spoon serves as a metaphor for those living on the land who need to cooperate so as to ensure there are enough resources for everyone and no one person or community takes more than they need. This idea is also echoed in Robin Wall Kimmerer's (2013) book Braiding Sweetgrass in which she argues that to truly live sustainably, we must not commodify what nature offers up to us. She calls for something similar to a feminist gift-giving economy instead. Drawing on her childhood memories of picking wild strawberries and gifting them to loved ones while watching others weigh and measure their worth according to a different paradigm as an example, Kimmerer differentiates between the "private property economy" in which "the 'gift' is deemed to be 'free' because we obtain it free of charge, at no cost" and the feminist gift economy where "gifts are not free" (p. 4). She argues: 
The essence of the gift is that it creates a set of relationships. The currency of a gift economy is, at its root, reciprocity. In Western thinking, private land is understood to be a 'bundle of rights,' whereas in a gift economy property has a 'bundle of responsibilities' attached. (p. 4)

We believe that museums, as public institutions that display artifacts and artworks that speak to our shared human history and potential, have a similar "bundle of responsibilities". The ways in which these institutions go about acquiring, framing, presenting and sharing the objects in their collections can either foster or hinder reciprocal relationships with members of the public. Many of the examples we provided in this paper speak to attempts on the part of museums in Canada to establish meaningful relationships with artists and visitors so that all sides may partner more deliberately and equitably to face some of the greatest challenges we've encountered as a species and become agents of environmental change.

\section{REFERENCES}

Alberti, S. (2008). Constructing nature behind glass. Museum and Society, 6(2), 73-97.

Art Gallery of Ontario. (2015, December 11). Bonnie Devine's Woodlands [Video]. YouTube. https:// www.youtube.com/watch? $\mathrm{v}=\mathrm{dbNbRh04fuQ}$

Art Gallery of Ontario. (2017, November 15). Art Gallery of Ontario and National Gallery of Canada to co-present major exhibitions detailing the impact of humans on earth [Press Release]. https://ago.ca/ press-release/art-gallery-ontario-and-national-gallery-canada-co-present-major-exhibitions

Art Gallery of Ontario. (2018, September). Anthropocene. https://ago.ca/exhibitions/anthropocene

Bell, L., \& Clover, D. E. (2017). Critical culture: Environmental adult education in public museums. In A. Dentith \& W. Griswold (Eds.) Ecojustice adult education: Theory and practice (pp. 17-31). Jossey-Bass. https://doi.org/10.1002/ace.20218

Bergsdottir, A. (2016). Museums and feminist matters: Considerations of a feminist museology. Nordic Journal of Feminist and Gender Research, 24(2), 126-139. https://doi.org/10.1080/08038740.2016.1182945

Biesta, G. (2012). Becoming public: Public pedagogy, citizenship and the public sphere. Social \& Cultural Geography, 13(7), 683-697. https://doi.org/10.1080/14649365.2012.723736

Carson, F., \& Pajaczkowska, C. (Eds.). (2001). Feminist Visual Culture. Routledge.

Chakrabarty, D. (2019). Museums between globalisation and the Anthropocene. Museum International, 71(1-2), 12-19. https://doi.org/10.1080/13500775.2019.1638022

Clover, D. E., Oliveira de Jayme, B., Hall, B. L., \& Follen, S. (2012). The nature of transformation: Environmental adult education. Sense Publishing. https://doi.org/10.1007/978-94-6209-146-7

Clover, D. E., \& Sanford, K. (2016). Contemporary museums as pedagogic contact zones: Potentials of critical cultural adult education. Studies in the Education of Adults, 48(2), 127-141. http://dx.doi. org/10.1080/02660830.2016.1219495

Clover, D. E., Sanford, K., \& Johnson, K. (2018). Museum and gallery pedagogic strategies for change. International Journal of Lifelong Education, 37(1), 1-3. https://doi.org/10.1080/02601370.2017.140 6547

Clover, D. E., \& Spring, L. (2020). Adult education, learning, and museums: Charting pedagogical imperfections and their critical fault lines. In S. Brigham, R. Mitzi, \& K. Jubas (Eds), Adult education and lifelong learning in Canada: Critical Legacy (pp. 268-278). Thompson Educational Publishing. 
Clover, D., Taber, N., \& Sanford, K. (2018). Dripping pink and blue. Andragoška spoznanja, 24(3), 11-28. https://doi.org/10.4312/as.24.3.11-28

Coalition of Museums for Climate Justice. (2017). The case for cutting museum ties to big oil. https:// coalitionofmuseumsforclimatejustice.wordpress.com/2017/07/04/the-case-for-cutting-museum-tiesto-big-oil/

Code, L. (2003). Ecological thinking: The politics of epistemic location. Oxford University Press. https:// doi.org/10.1093/0195159438.001.0001

Commanda, E. (2016, January 13). Bonnie Devine's Battle for the Woodlands battles the status quo. Muskrat Magazine. http://muskratmagazine.com/bonnie-devines-battle-for-the-woodlands-battlesthe-status-quo/

Emeagwali, G., \& Shizha, E. (Eds.). (2016). African indigenous knowledge and the sciences: Journeys into the past and present. Sense Publishers. https://doi.org/10.1007/978-94-6300-515-9

Evans, T. (2012). Occupy education: Living and learning sustainability. Peter Lang.

Forest-Hammond, E. (2020). A human history of Tl'ches, 1860-1973 [unpublished Master's Thesis]. University of Victoria.

Gordon-Walker, C. (2018). Exhibiting nation: Multi-cultural nationalism (and its limits) in Canada's museums. UBC Press.

Gregorčič, M. (2018). Silenced epistemologies: The power of testimonies and critical auto/biographies for contemporary education. Andragoška spoznanja, 24(1), 61-75. https://doi.org/10.4312/ as.24.1.61-75

Hall, S., Evans, J., \& Nixon, S. (2013). (Eds.). Representation. Sage.

Hempel, M. (2014). Ecoliteracy: Knowledge is not Enough. In State of the World 2014: Governing for Sustainability (pp. 41-52). Island Press. https://doi.org/10.5822/978-1-61091-542-7_4

Jahanbegloo, R, \& Shiva, V. (2013). Talking Environment: Vandana Shiva in Conversation with Ramin Jahanbegloo. Oxford University Press. https://doi.org/10.1093/acprof:oso/9780198091776.001.0001

Janes, R. R. (2009). Museums in a troubled world. Routledge. https://doi.org/10.4324/9780203877456

Janes,R.R., \&Sandell,R.(Eds).(2019).Museumactivism. Routledge.https://doi.org/10.4324/9781351251044

Johnson, K. (2020). Unsettling exhibition pedagogies: Troubling stories of the Nation with Miss Chief [unpublished Master's thesis]. University of Victoria.

Kimmerer, R. W. (2013). Braiding Sweetgrass: Indigenous Wisdom, Scientific Knowledge, and the Teaching of Plants. Milkweed Editions.

Klein, N. (2014). This changes everything: Capitalism vs the climate. Knopf.

Leichner, P. (2013). Thanks but no tanks-perceptions put into play [Conference presentation]. British Columbia Museums Association conference, Parksville, British Columbia.

Lyons, S., \& Bosworth, K. (2019). Museum in the climate emergency. In R. Janes \& R. Sandell (Eds.), Museum activism (pp. 174-185). Routledge.

Machin, R. (2008). Gender representation in the natural history galleries at the Manchester Museum. Museum and Society, 6(1), 54-67.

Marstine, J. (Ed.). (2006). New museum theory and practice. Blackwell Publishing.

McGregor, D. (2012). Traditional knowledge: Considerations for protecting water in Ontario. The International Indigenous Policy Journal, 3(3), 1-21. https://doi.org/10.18584/iipj.2012.3.3.11

Mignolo, W. D., \& Nanibush, W. (2018). Thinking and engaging with the decolonial. Afterall, a Journal of Art, Context and Enquiry, 45, 24-29. https://doi.org/10.1086/698391

Nixon, R. (2011). Slow violence and the environmentalism of the poor. Harvard University Press.

Orr, D. (1996). Slow Knowledge. Conservation Biology, 10(3). 699-702. https://doi.org/10.1046/j.15231739.1996.10030699.x 
Orr, D. (2004). Earth in Mind: On Education, Environment, and the Human Prospect. Island Press.

Phillips, R. (Ed.). (2011). Museum pieces: Towards the indigenization of Canadian museums. McGillQueen's University Press.

Porr, M., \& Mathews, J. (Eds.). (2019). Interrogating human origins decolonisation and the deep human past. Routledge.

Serafini, P., \& Garrard, C. (2019). Fossil fuel sponsorship and the contested museum: Agency, accountability and arts activism. In R. Janes \& R. Sandell (Eds.), Museum Activism (pp. 69-80). Routledge.

Shiva, V. (1993). Monocultures of the Mind. Trumpeter, 10(4). http://trumpeter.athabascau.ca/index.php/ trumpet/article/view/358/563

Solnit, R. (2014, April 24). Woolf's darkness: Embracing the Inexplicable. The New Yorker. https:// www.newyorker.com/books/page-turner/woolfs-darkness-embracing-the-inexplicable

Steeds, L. (2014). Exhibition. Whitechapel Gallery.

Trofanenko, B. (2006). Interrupting the gaze: Reconsidering authority in the museum. Journal of Curriculum Studies, 38(1), 49-65. https://doi.org/10.1080/00220270500038511

Truth and Reconciliation Commission of Canada. (2012). Truth and Reconciliation Commission of Canada: Interim report. https://www.falconers.ca/wp-content/uploads/2015/07/TRC-Interim-Report.pdf

UNESCO. (1997). Museums, libraries and cultural heritage: Democratising culture, creating knowledge and building bridges. UIE.

Whitehead, C. (2009). Museums and the construction of disciplines: Art and archaeology in nineteenth-century Britain. Gerald Duckworth \& Co. 